УДК 902.34

https://doi.org/10.24852/2587-6112.2021.6.338.347

\title{
ПОЛЕВАЯ КОНСЕРВАЦИЯ КАК ПОДГОТОВИТЕЛЬНЫЙ ЭТАП ДЛЯ ПРОВЕДЕНИЯ ЛАБОРАТОРНЫХ РЕСТАВРАЦИОННЫХ РАБОТ С АРХЕОЛОГИЧЕСКИМИ АРТЕФАКТАМИ ИЗ ТЕКСТИЛЯ
}

\author{
(C) 2021 г. О.Л. Швец, Е.А. Зайцева, А.В. Кениг
}

Археологические находки из текстиля относятся к категории редких по причине своей плохой сохранности. Найденные и зафиксированные в ходе полевых работ изделия и фрагменты изделий из текстиля часто просто не доходят до реставрации из-за того, что разрушаются в процессе зачистки погребения, изъятия из почвы или при транспортировке. Применение методов полевой консервации позволяют сохранить и малотравматично извлечь хрупкие фрагменты текстиля из погребения и без повреждений доставить в стационарную реставрационную лабораторию. Все методы полевой консервации носят временный характер. В статье, на материалах конкретного памятника, описан метод полевой консервации текстиля с применением низкомолекулярного раствора полиэтиленгликоля марки 200 и антисептика Лизоформин-3000 прямо в раскопе, с момента обнаружения до места постоянного хранения.

Ключевые слова: археологический текстиль, могильник Горноправдинский (ХМАО-Югра), полевая консервация, реставрация текстиля, ПЭГ, лизоформин.

\section{FIELDCONSERVATIONOFARCHAEOLOGICALTEXTILEARTEFACTS AS A PREPARATORY STAGE FOR LABORATORY RESTORATION}

\author{
O.L. Shvets, E.A. Zaytseva, A.V. Kenig
}

Archaeological textile finds are rare due to their poor preservation state. Unearthed and recorded textile artefacts or their fragments often simply do not reach the restoration stage as they are destroyed during burial cleaning, removal from the soil, or during transportation. The use of field conservation methods allows for preservation and relatively painless extraction of fragile textile fragments, with delivery to a stationary restoration laboratory without further damage. All field conservation methods are temporary measures. The paper describes a method of field conservation of textile from a certain archaeological site using a low molecular weight solution of polyethylene glycol (PEG-200) and antiseptic Lysoformin-3000 in situ from the moment of discovery to the allocation of finds to a permanent storage facility.

Keywords: archaeological textile, Gornopravdinsky burial site, Khanty-Mansi Autonomous Okrug-Yugra, field conservation, textile restoration, PEG, lysoformin

\section{Введение}

Важным этапом в комплексе реставрационных работ со всеми найденными в процессе археологических раскопок артефактами является выполнение полевых консервационных работ.

Первоначально все предметы находятся в непотревоженном культурном слое, где к ним затруднен доступ кислорода, нет резких перепадов температуры, сохраняется относительная постоянная влажность. При извлечении из земли, из не менявшейся длительное время среды, находки, выполненные из различных видов материалов, вновь начинают активно разрушаться. Такое резкое изменение условий особенно губительно для изделий из текстиля - органического материала, уникального и редкого не только по регулярности встре- чаемости в археологических комплексах, но особенно по степени своей информативности.

Специфика археологического текстиля состоит в том, что текстильные волокна являются крайне хрупким органическим материалом и далеко не всегда выдерживают воздействие экстремальных факторов в условиях захоронений, в связи с чем изделия или полностью исчезают, или доходят до нас в сильно деструктированном виде. Поэтому для предотвращения дальнейших разрушений изделий из текстиля необходимо проведение первичных консервационных работ - комплекса временных мер по оказанию помощи находкам - сразу же после обнаружения предмета непосредственно в раскопе. Первичная консервация придает предметам временную пластичность и прочность, что позволяет корректно изъять их из захороне- 


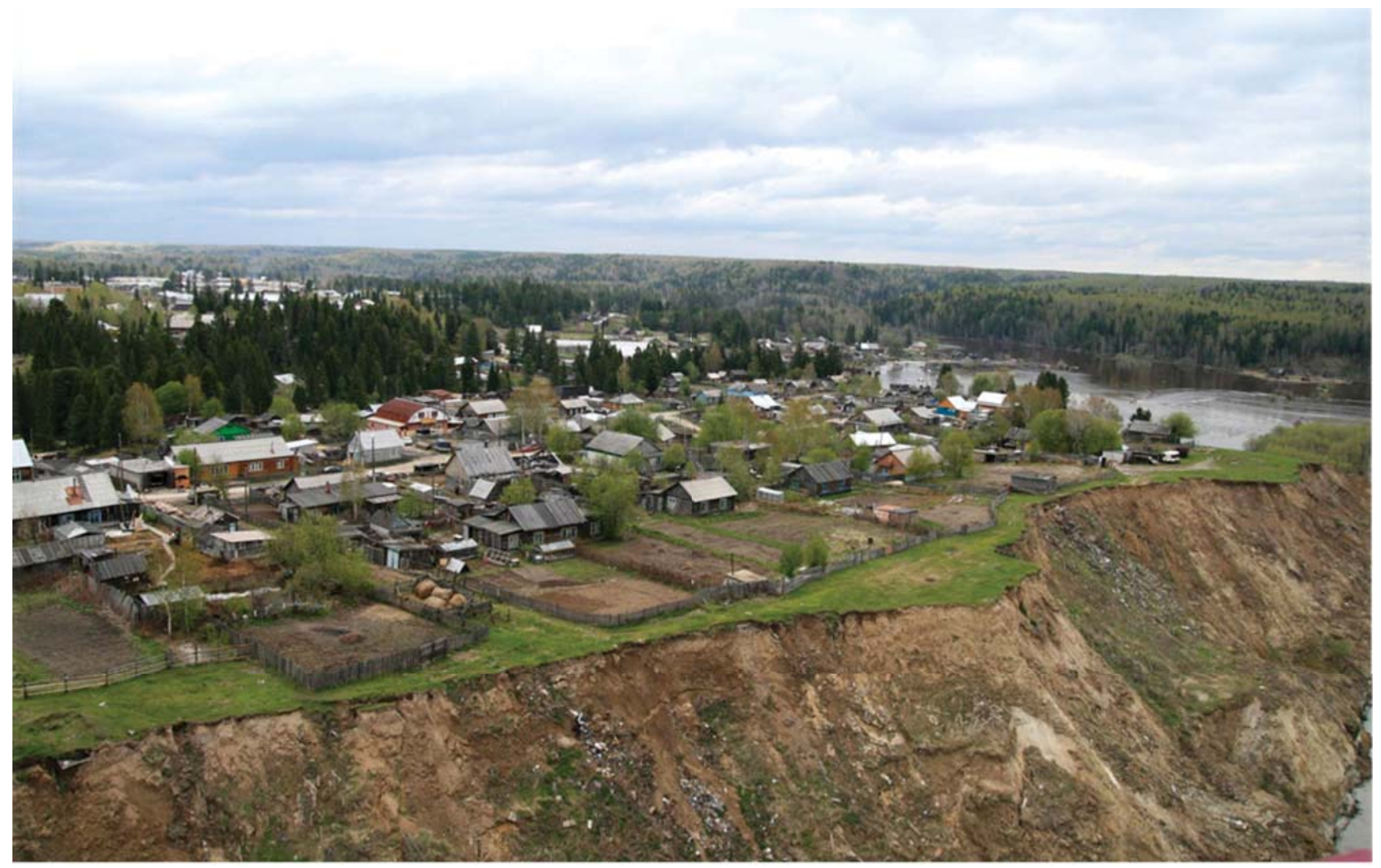

Рис. 1. Поселок Горноправдинск (Ханты-Мансийский район, ХМАО-Югра).

Fig. 1. Gornopravdinsk village, Khanty-Mansi Autonomous Okrug-Yugra

ния, обеспечивает подготовку к транспортировке в стационарную реставрационную лабораторию и облегчает проведение дальнейших реставрационных работ.

Обнаруженные в ходе археологических раскопок остатки одежды обычно сильно повреждены, прежде всего в результате гуминового разложения органических останков погребенного и воздействия почвенных минеральных веществ, а также из-за жизнедеятельности микроорганизмов, плесневых грибов, растений и насекомых.

По степени сохранности археологический текстиль можно разделить на три группы:

1. Одежда погребенного или отдельные eе фрагменты, обладающие достаточной прочностью. При извлечении из раскопа не повреждаются механически, не рассыпаются под тяжестью своего веса. Обычно смятые, но относительно крепкие ткани, которые в момент обнаружения еще пластичны за счет сохранения некоторой естественной влажности (свободной воды в материале);

2. Фрагменты одежды, спрессованные в слоистую плотную корку, отделение которой от костяка без механических повреждений невозможно. Ветхие, хрупкие, сухие или, наоборот, с переизбытком влаги ткани настолько слабы из-за деструкции волокон, что при любом воздействии на них сразу рассыпаются или размазываются;

3. Следы ткани, сохраняющие ее фактуру и даже цвет (Полевая консервация..., 1987).

Текстильные изделия, найденные в процессе проведения спасательных археологических исследований на могильнике Горноправдинский с датировкой памятника XVIII-XIX веков, можно отнести к первой группе.

\section{Природно-климатические условия}

Исследуемый памятник в соответствии с административным делением расположен в черте поселка городского типа Горноправ-

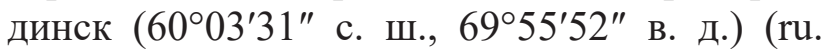
wikipedia.org) Ханты-Мансийского района Ханты-Мансийского автономного округа Югры.

По ландшафтному районированию территория относится к Западно-Сибирской физико-географической стране, Обско-Иртышской пойменно-террасовой интразональной ландшафтной области (Москвина, Козин, 2001). Памятник расположен в урочище Филинская гора, где средние отметки составляют 79-81 м над уровнем моря (в Балтийской системе 


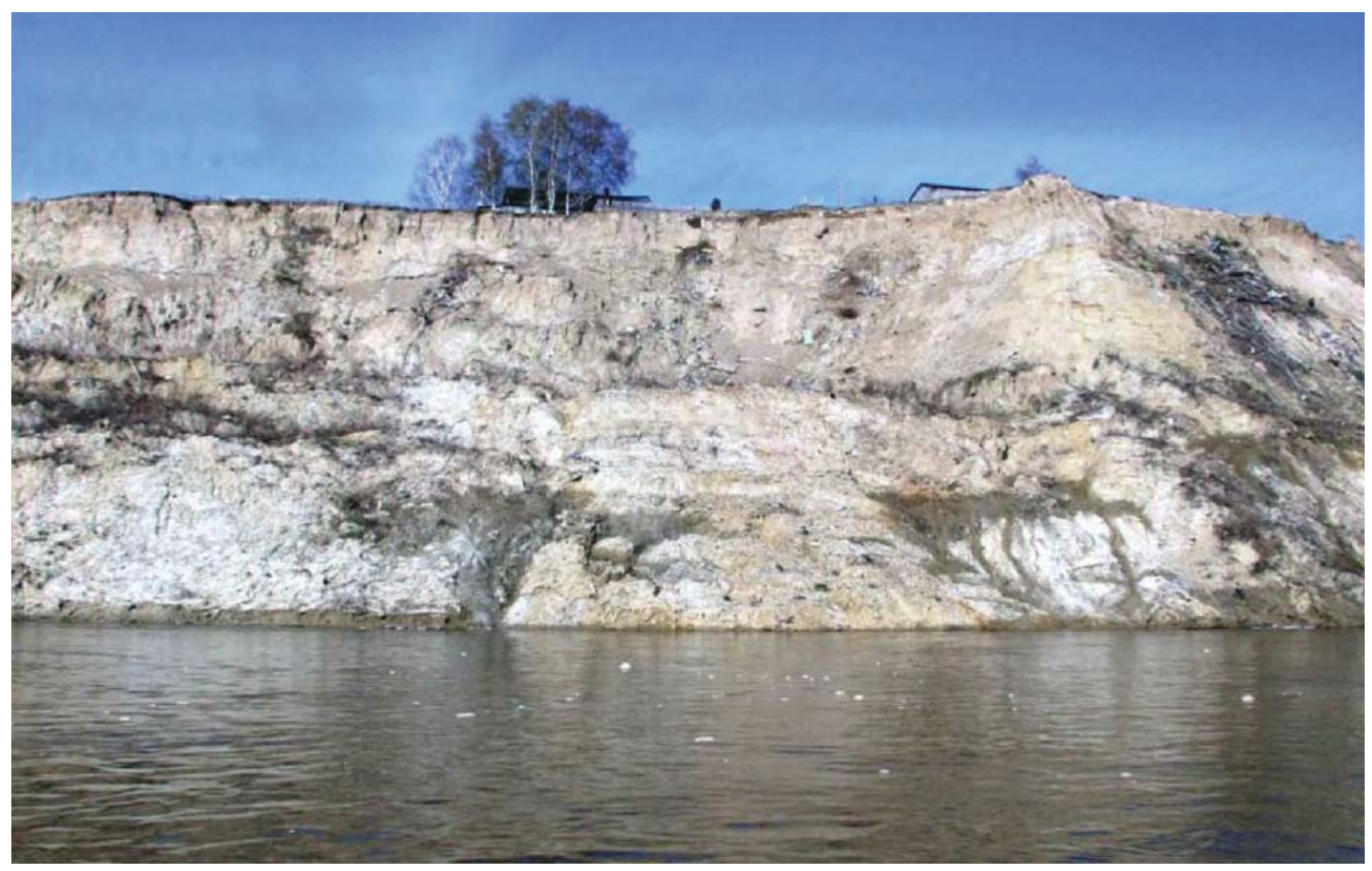

Рис. 2. Могильник Горноправдинский. Общий вид с р. Иртыш (вид с запада).

Fig. 2 General view of the Gornopravdinsky burial site from Irtysh river (west side)

высот). С юга урочище разрезает река Кайгарка, которая является правым притоком реки Иртыш, а с севера - проточное озеро Подгорный сор (рис. 1).

По гидролого-климатическому районированию территория относится к зонам избыточного и весьма избыточного увлажнения (коэффициент увлажнения - 1,2) при недостаточной теплообеспеченности. Средняя годовая температура воздуха $-1,1{ }^{\circ} \mathrm{C}$, зимние месяцы отличаются устойчивыми низкими температурами, самый холодный месяц -январь со средней температурой $-19,8^{\circ} \mathrm{C}$. Продолжительность периода с положительными среднесуточными температурами составляет в среднем 187 дней. Основным источником поступления влаги являются атмосферные осадки. Среднегодовое количество осадков 494 мм. Максимальное количество осадков выпадает с апреля по октябрь (75-83\%), особенно много в июле и августе. Зимой, в связи с установлением антициклонального режима и низкой температуры, количество осадков составляет $17-20 \%$ от годового количества. Средняя высота снежного покрова составляет 57 см, максимальная 90 см (Экология, 1997).
Биоклиматические условия почвообразования, свойственные средней тайге, усугубляются «отепляющим» влиянием пойменных экосистем Оби и Иртыша. Так, для данного района характерен механический состав почв. Это подзолисто-элювиально-глееватые, формирующиеся под елово-кедрово-пихтовыми зеленомошными лесами на суглинистых и глинистых породах в условиях значительной расчлененности рельефа на холмисто-увалистых «материках» (Обзор, 1997).

Уникальность памятника заключается в сохранности предметов из органических материалов, таких как деревянные колоды, дощатые гробы, кожаная обувь, а также изделия из ткани, что обычно характерно для более северных памятников. В частности, это касается текстильных материалов, обнаруженных в ходе раскопок, которые в целом относятся к категории редких находок и, как правило, не сохраняются. Исключение составляют памятники, расположенные в зоне вечной мерзлоты или содержащие бронзовые предметы. Так, значительные коллекции археологического текстиля были получены в ходе раскопок Мангазеи, Надымского городка, Березово (Визгалов, Пархимович, Глушкова и др., 2006; 


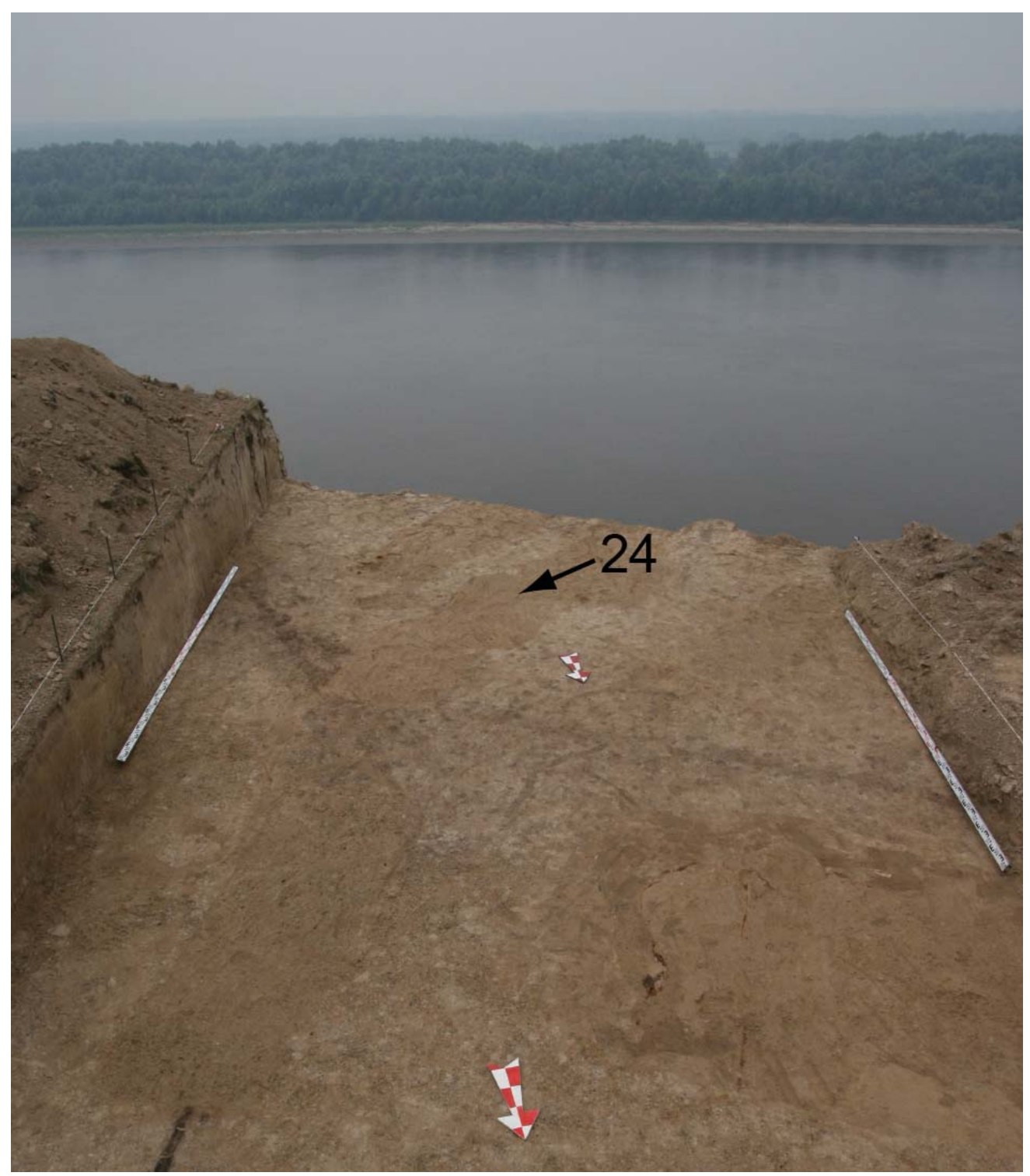

Рис. 3. Расположение погребения № 24 на общем виде раскопа.

Fig. 3 Location of burial N 24 on general excavation view

Визгалов, Пархимович, 2008; Кардаш, 2009 и др.), а также из археологических памятников Томско-Нарымского Приобья и Прииртышья (Богомолов, 1990; Глушкова, 2002; Киреева, 2004; и др.).

Могильник Горноправдинский не относится к памятникам, расположенным в зоне вечной мерзлоты, но все же для этой территории характерна сезонная мерзлота. Расположение на краю постоянно разрушающегося берега (рис 2), значительная глубина погребений (до 2-х метров), суглинистые почвы, для которых характерна низкая водопроницаемость и затруднен доступ воздуха - все это способствует тому, что в холодный период года грунт промерзает на большую глубину, а период протаивания не превышает 4-х месяцев.

\section{Археологический контекст}

За время исследований могильника выявилась определенная закономерность в степени сохранности текстильных образцов и способе захоронения, а именно: текстильные предметы, обнаруженные в деревянных колодах, несмотря на фрагментированный характер, в целом были лучшей сохранности, чем те, что обнаружены в дощатых гробах. Данное обстоятельство объясняется тем, что гробы в отличие от колод имели более слабую конструкцию, в результате чего быстрее продавливались землей и разрушение органических предметов шло быстрее (Зайцева, 

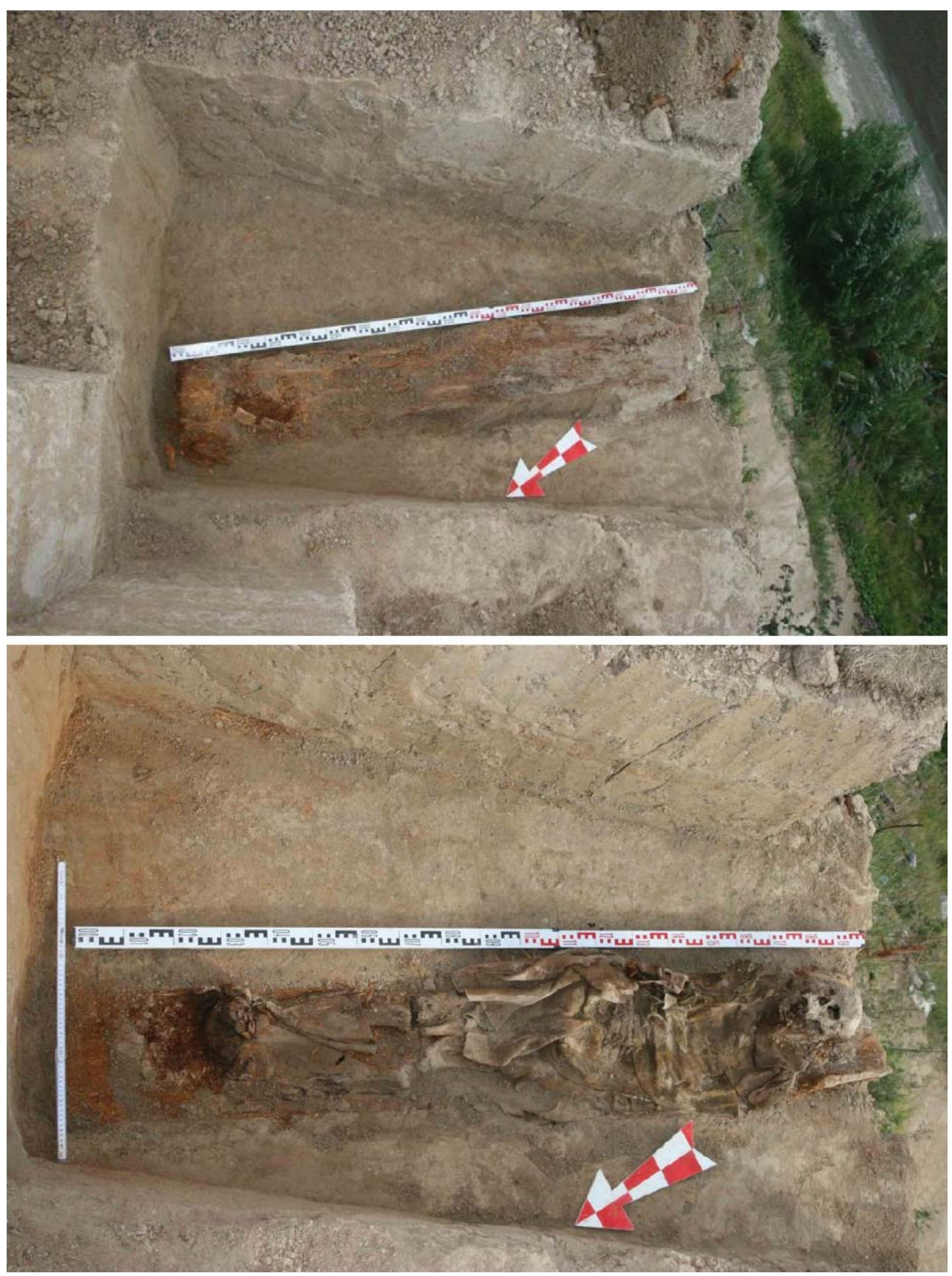

Рис. 4. Выборка погребения до материка с фиксацией захоронения (А). Расположение скелета и предметов в захоронении (Б).

Fig. 4 Burial excavation and finds recording (A) Skeleton and burial goods (B)

2008, 2009; Глушкова, Зайцева, 2011; Кениг, Зайцева, 2012).

В 2012 году, при выборке заполнения ямы серо-желто-коричневого суглинка, в погребении № 24 (сектор 3, рис. 3) было обнаружено захоронение в деревянной колоде (рис. 4: А). Нивелировочные отметки уровня залегания колоды составляют -192-194 см от дневной поверхности (Зайцева, 2016).

После расчистки и снятия крышки колоды плохой сохранности были обнаружены костные останки человека, одетого предположительно в пальто (рис. 4: Б). Несмотря на ветхость крышки и самой колоды, останки не были затянуты глиной. После удаления незначительного количества глины мягкой кистью, для сохранения целостности материала пальто, было принято решение провести консервацию ткани. Первоначальное определение типа материала - сукно (шерсть).

Мероприятия по полевой консервации.

Существующие и применяемые ранее методики пластификации и консервации археологического текстиля не отвечают специфике найденного материала. Рекомендованное применение химических веществ, 

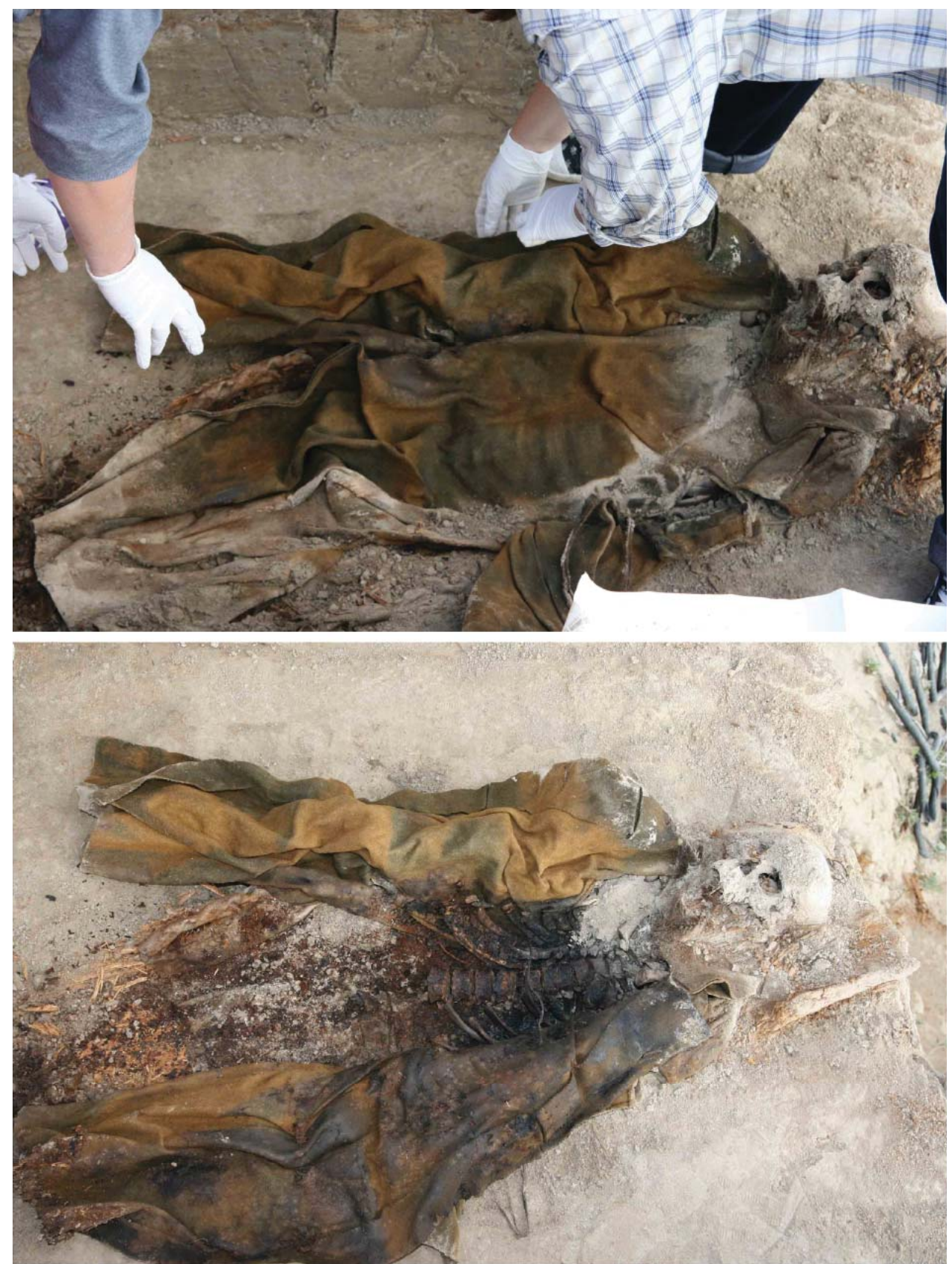

Рис. 5. Разбор погребения - раскрытие пальто (А), изъятие антропологического материала (Б).

Fig. 5 Burial finds extraction: unwrapping of the coat (A) Removal of the anthropological material (B)

таких как перхлорэтилен (Полевая консервация..., 1987), недопустимо (Синицына, http://art-fenomen.ru). Это одновременно вредит предмету, реставратору, проводящему консервационные работы, и окружающей среде. Малоэффективен рекомендованный водно-спиртовой раствор глицерина (Никитин, 2002), который из-за плотности ткани не проникает внутрь, а оседает на поверхности и не укрепляет структуру нитей.

Поэтому было необходимо найти способ, отвечающий требованиям работы с конкретным материалом, в данном случае разработать и опробовать новую методику консервации материала прямо в погребении. Лабораторные наблюдения иприобретенный опыт по изъятию текстильных изделий (шелк, шерсть, войлок) из мокрых глиняных монолитов (Полосьмак, Богданов, Цэвээндорж, 2011; Полосьмак 2014; Полосьмак, Богданов, 2015) с применением временного консерванта низкомолекулярного полиэтиленгликоля (ПЭГ-200) (5\%) позволили предположить возможность его применения прямо в раскопе. Как антисептик был использован концентрат «Лизоформин-3000» (до 5\%) производства фирмы «Лизоформ. Др. 


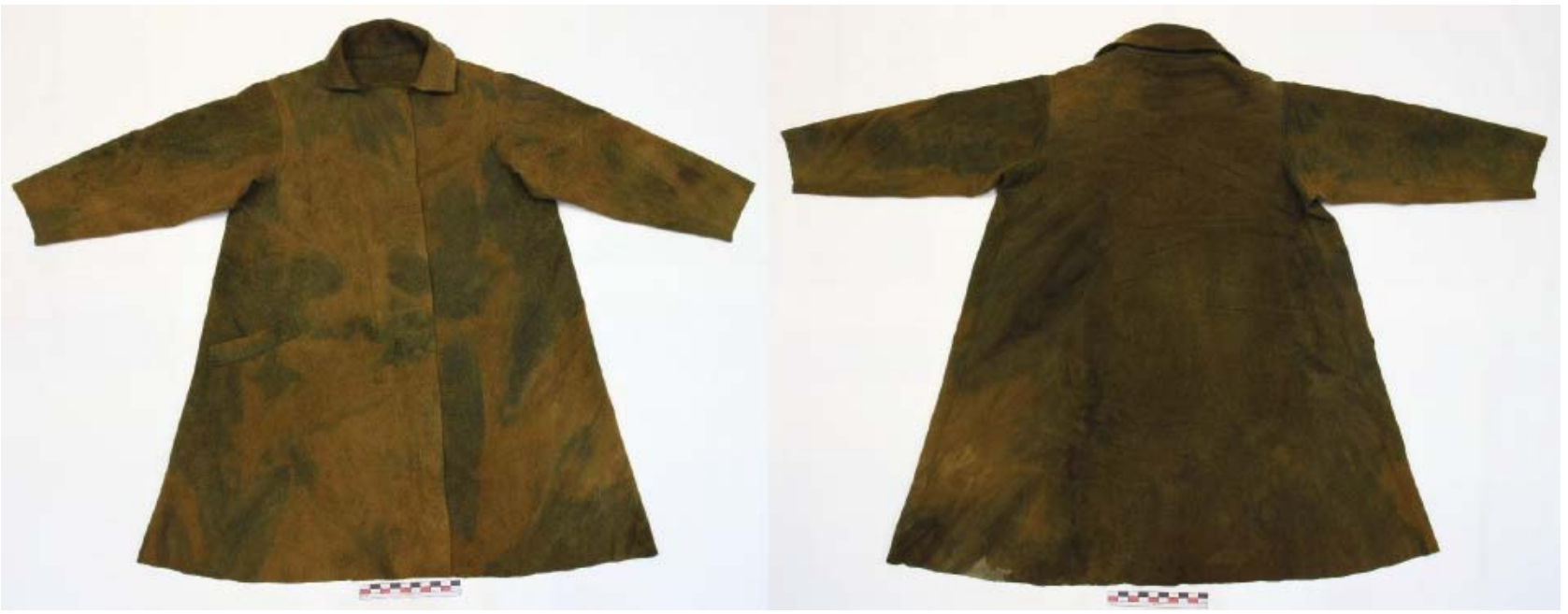

Рис. 6. Предмет - пальто после реставрации - перед (А), спинка (Б).

Fig. 6 The coat after restoration: Front (A), Back (B)

Ханс Роземани ГмбХ» (Германия) (Митковская, Бидзиля, 2011; dezshare.ru/d...).

Выбор данного консерванта и антисептика был обусловлен их водорастворимостью и наличием остаточной влаги в ткани, за счет которой проходило быстрое проникновение в нее раствора. Зачистка погребения проводилось при дневной температуре в интервале от 25 до $35^{\circ} \mathrm{C}$, что является оптимальным режимом для использования выбранного консерванта. Введение водного раствора консерванта началось с момента обнаружения фрагмента ткани на погребенном при зачистке погребения. Консервация проводилась многократно при помощи пульверизатора. После каждого орошения, для поддержания уровня влаги и более глубокого проникновения консерванта в материал, пальто максимально плотно прикрывалось листами крафтовой бумаги и полиэтилена.

Такой способ консервации восстановил временную гигроскопическую влажность и пластичность нитей. Он позволил раскрыть полы пальто без повреждения ткани (рис. 5: A).

После консультации с антропологами, для сохранения целостности спинки и более легкого отделения костей скелета от нее, консервационные работы проводились вместе с остатками костяка (рис. 5: Б).

Консервация затем позволила аккуратно отделить костные останки от ткани и провести их изъятие из погребения. В ходе работ обнаружилась полная утрата нитей соединительных швов деталей пальто. Это существенно облегчило их извлечение из раскопа на жест- кую картонную подложку. Затем детали пальто, отделив их друг от друга листами бумаги, сложили в специально сделанную по размерам предмета коробку, которую зафиксировали пищевой пленкой. Во избежание возникновения плесени и осуществления досушивания ткани в коробке были прорезаны небольшие отверстия.

Bce необходимые археологические работы - раскрытие и зачистка погребения, фотофиксация, зарисовка и изъятие текстильной находки - желательно проводить в течение одного рабочего дня. По завершении полевого сезона археологическое пальто было передано на хранение в Музей природы и человека города Ханты-Мансийска.

Укрепленная в полевых условиях структура ткани и способность ПЕГ регулировать влажность волокон изделия после обработки (Никитин, 2002) позволила деталям пальто в условиях климат-контроля дождаться проведения реставрационных работ.

Благодаря осуществлению консервации in situ и последующим профессиональным условиям хранения проведение реставрационных работ прошло эффективнее и без нанесения текстилю новых травм (рис. 6).

\section{Заключение}

Подобранный метод и проведенная в раскопе с момента обнаружения находок из текстиля и до их изъятия полевая консервация с применением ПЭГ-200 как временного консерванта позволили в полевом сезоне этого года стабилизировать материалы и малотравматично изъять из раскопа пальто из сукна, халат из растительных нитей, детские 
вязанные носочки из шерстяной нити, а также без повреждений транспортировать находки до постоянного места хранения. Поэтому этот метод можно считать пригодным для использования.
Примененный в последовавших полевых сезонах (2015, 2017 год) вышеописанный способ консервации помог сохранить фрагменты изделий из сукна, шелка, растительных нитей.

\section{ЛИТЕРАТУРА}

Богомолов В.Б. Ткани XVII в. тюркского населения бассейна р. Тары // Этнографо-археологические комплексы: проблемы культуры и социума. / Отв. ред. Н.А. Томилов. Т.1. Культура тарских татар. Новосибирск: Наука, 1990. С. 112-116.

Визгалов Г.П., Пархимович С.Г. Мангазея: новые археологические исследования (материалы 20012004 гг.). Екатеринбург-Нефтеюганск: изд-во «Магеллан», 2008. 296 с.

Визгалов Г.П., Пархимович С.Г., Глушкова Т.Н., Киреева Е.В., Сутула А.В. Текстиль Мангазеи (начало XVII в.) // Археология, этнография и антропология Евразии. 2006. №1 (25). С. 117-131.

Глушкова Т.Н. Археологические ткани Западной Сибири. Сургут: РИО СурГПИ , 2002. 206 с.

Глушкова T.H., Зайцева Е.А. Текстиль XVIII-XIX вв. по материалам могильника Горноправдинский // Культура русских в археологических исследованиях / Отв. ред. Л.В. Татауровой. Омск: Издательство Омский институт (филиал) РГТЭУ, 2011. С. 283-290.

Горноправдинск. URL: https://ru.wikipedia.org/wiki/\%D0\%93\%D0\%BE\%D1\%80\%D0\%BD\%D0\%B E\%D0\%BF\%D1\%80\%D0\%B0\%D0\%B2\%D0\%B4\%D0\%B8\%D0\%BD\%D1\%81\%D0\%BA (Дата обращения 25.03.2021)ю

Зайцева E.A. Отчет о научно-исследовательской работе. Раскопки могильника Горноправдинский и территории, прилегающей к объекту культурного наследия «Здание церкви вознесения господня в п. Горноправдинск Ханты-Мансийского района Ханты-Мансийского автономного округа - Югры, проведенные летом 2012г. в 3 книгах. Книга 1. Ханты-Мансийск. 2016 г., С. 68-69.

Зайщева E.A. Противоаварийные археологические раскопки на могильнике Горноправдинский в полевом сезоне 2008 г. (предварительные результаты) // Ханты-Мансийский автономный округ в зеркале прошлого. Вып. 7. / Отв. Ред. Я.А. Яковлев. Томск; Ханты-Мансийск; Изд-во Том. Ун-та, 2009. С. 302-307.

Зайцева E.A. Противоаварийные работы на могильнике Горноправдинский в Ханты-Мансийском районе Ханты-Мансийского автономного округа - Югры в полевом сезоне 2007 года (предварительные результаты) // Сохранение археологического наследия в условиях интенсивного хозяйственного освоения: опыт, проблемы, решения: сборник докладов. Ханты-Мансийск: Полиграфист, 2008. С. 51-58.

Инструкция № 06/07 по применению средства «Лизоформин 3000» для целей дезинфекции, очистки и стерилизации производства фирмы «Лизоформ. Др. Ханс Роземани ГмбХ» (Германия). URL: http:// dezshare.ru/documents/223/Lisoformin_3000_06-07_2007.pdf. Дата обращения 09.03.2021.

Кардаш O.В. Надымский городок в конце XVI - первой трети XVIII вв. История и материальная культура. Екатеринбург-Нефтеюганск: Магеллан, 2009. 360 с.

Кениг А.В., Зайцева Е.А. Итоги археологических исследований в полевом сезоне 2012 года // Вестник угроведения. 2012. Вып. 4 (11). С. 156 - 161.

Киреева E.B. Отражение традиций русского ткачества в текстильных западносибирских археологических материалах XVII - XIX вв. // Россия: история и современность. Тезисы VI межвузовской конференции студентов и молодых ученых. Сургут: РИО СурГПИ, 2004. С. 14-17.

Митківська T.I., Бідзіля В.О. Дослідження препарату Лізоформін-Спец як антисептика для музейних пам'яток. // VIII Міжнародна науково-практична конференція. Досягнення, реставрація та превентивна консервація музейних памятніков. Сучасний стан. Перспективи розвитку. Київ, 2011. С. 250-254.

Москвина Н.Н., Козин В.В. Ландшафтное районирование Ханты-Мансийского автономного округа. Ханты-Мансийск, 2001. 36 с.

Никитин М.К., Мельникова Е.П. Химия в реставрации. СПб: «Центр ТЕХИНФОРМ», 2002. С. $222-228$.

Обзор "О состоянии окружающей природной среды Ханты-Мансийского автономного округа в 1996 году". Ханты-Мансийск, 1997. С. 20 - 25.

Полевая консервация археологических находок (текстиль, металл, стекло) / сост. А. К. Елкина и др.. М.: ВНИИР, 1987. 39 с.

Полосьмак Н.В. Степная мода. // Наука из первых рук. 2014. № 6. С. 64-87. 
Полосьмак Н.В., Богданов Е.С. Курганы Суцзуктэ (Ноин-Ула, Монголия). Часть 1. Новосибирск: ИНФОЛИО, 2015. $136 \mathrm{c.}$

Полосьмак Н.В., Богданов Е.С., Цэвээндорж Д. Двадцатый ноин-улинский курган. Новосибирск: ИНФОЛИО, 2011. 184 с.: ил.

Синицына Н.П. Опыт исследования, реставрации и реконструкции предметов археологического текстиля из некрополя Вознесенского монастыря. Библиотека OОО "Феномен". URL: http://art-fenomen. ru/restoration/publications/statya-2/. Дата обращения 09.03.2021.

Экология Ханты-Мансийского автономного округа / Под ред. В.В. Плотникова. Тюмень: СофтДизайн, 1997. 286 с.

\section{Информация об авторах:}

Швец Ольга Львовна. ведущий художник-реставратор, Институт археологии и этнографии СО PAН (г. Новосибирск, Россия); ribcz@ngs.ru

Зайцева Евгения Александровна, кандидат исторических наук, ООО «НИПИ «ЭтноАрхео Центр», ( г. Ханты-Мансийск, Россия); e.zaitseva@archeocenter.ru

Кениг Александр Владимирович, кандидат исторических наук, Югорская лаборатория археологии и этнологии Института археологии и этнографии СО РАН (г. Новосибирск, Россия); akenig@bk.ru

\section{REFERENCES}

Belich, I. V. 1990. In Tomilov, N. A. (ed). Etnografo-arkheologicheskie kompleksy: Problemy kul'tury $i$ sotsiuma (Ethnographic-Archaeological Complexes: Issues of Culture and Society) 1. Novosisbisrsk: "Nauka" Publ., 112-116 (in Russian).

Vizgalov, G. P., Parkhimovich, S. G. 2008. Mangazeia: novye arkheologicheskie issledovaniia (materialy 2001-2004 gg.) (Mangazeya: New Archaeological Studies (Materials of 2001-2004). Nefteyugansk; Yekaterinburg: "Magellan" Publ. (in Russian).

Vizgalova, G. P., Parkhimovich, S. G., Glushkova, T. N., Kireeva, E. V., Sutula, A. V. 2006. In Arkheologiya, etnografiia i antropologiia Evrazii (Archaeology, Ethnology \& Anthropology of Eurasia) 25 (1), 117-131 (in Russian).

Glushkova, T. N. 2002. Arkheologicheskie tkani Zapadnoi Sibiri (Archaeological Tissues from Western Siberia). Surgut: Editorial and Publishing Unit of Surgut State Pedagogical University (in Russian).

Glushkova, T. N., Zaitseva, E. A. 2011. In Tataurova, L. V. (ed.). Kul'tura russkikh v arkheologicheskikh issledovaniiakh (Culture of the Russians in Archaeological Research). Omsk, 283-290 (in Russian).

Gornopravdinsk. Available at: https://ru.wikipedia.org/wiki/\%D0\%93\%D0\%BE\%D1\%80\%D0\%BD\%D 0\%BE\%D0\%BF\%D1\%80\%D0\%B0\%D0\%B2\%D0\%B4\%D0\%B8\%D0\%BD\%D1\%81\%D0\%BA (accessed: 25.03.2021) (in Russian).

Zaitseva, E. A. 2016. Otchet o nauchno-issledovatel'skoi rabote. Raskopki mogil'nika Gornopravdinskii $i$ territorii, prilegajushhei $k$ obektu kul'turnogo naslediia "Zdanie cerkvi voznesenija gospodnja $v p$. Gornopravdinsk Hanty-Mansijskogo rajona Hanty-Mansijskogo avtonomnogo okruga - Iugry, provedennye letom 2012g. v 3 knigakh (Report on Scientific Research Work. Excavations of Gornopravdinsky Burial Ground and the Territory Adjacent to the Cultural Heritage Site "The Building of the Church of Ascension in Gornopravdinsk of Khanty-Mansiysky District of Khanty-Mansi Autonomous Okrug-Yugra in the Summer of 2012, in 3 Books.). Khanty-Mansiisk, 68-69 (in Russian).

Zaitseva, E. A. 2009. In Yakovlev, Ya. A. (ed.). Khanty-Mansiyskiy avtonomniy okrug v zerkale proshlogo (Khanty-Mansi Autonomous Area in the Mirror of the Past) (7). Tomsk; Khanty-Mansiysk: Tomsk State University, 302-307 (in Russian).

Zaitseva,E.A.2008. In Sokhranenie arheologicheskogonasledijavusloviiakhintensivnogokhoziaistvennogo osvoeniia: opyt, problemy, resheniia (Preservation of Archaeological Heritage in the Conditions of Intensive Economic Development: Experience, Issues, Solutions). Khanty-Mansiysk: "Poligrafist" Publ., 51-58 (in Russian).

Instruktsiia № 06/07 po primeneniiu sredstva «Lizoformin 3000» dlia celei dezinfekcii, ochistki i sterilizatsii proizvodstva firmy «Lizoform. Dr. Hans Rozemani GmbH» (Germaniia) (Instruction No. 06/07 on the Use of Lysoformin 3000 for Disinfection, Cleaning and Sterilization, Produced by Lysoform Dr. Hans Roseman GmbH (Germany)). Available at: http://dezshare.ru/documents/223/Lisoformin_3000_06-07_2007. pdf (accessed: 09.03.2021) (in Russian).

Kardash, O. V. 2009. Nadymskii gorodok v kontse XVI - pervoi treti XVIII vv. Istoriia i material'naia kul'tura (Nadym Town at the End of the 16th - First Third of the 18th Centuries. History and Material Culture). Yekaterburg-Neftyugansk: "Magellan" Publ. (in Russian). 
Kening, A. V., Zaitseva, E. A. 2012. In Vestnik ugrovedeniia (Bulletin of Ugric Studies) 11 (4), 156-161 (in Russian).

Kireeva, E. V. 2004. In Rossiia: istoriia i sovremennost' (Russia: History and Contemporaneity). Surgut, 14-17 (in Russian).

Moskovina, N. N., Kozin, V. V. 2001. Landshaftnoe raionirovanie Khanty-Mansiiskogo avtonomnogo okruga (Landscape Zoning of Khanty-Mansi Autonomous Okrug). Khanty-Mansiysk (in Russian).

Mitkivska, T. I., Bidzilya, V.O. 2011. In VIII Mizhnarodna naukovo-praktichna konferentsiia. Dosiagnennia, restavratsiia ta preventivna konservatsiia muzeinikh pamiatnikov. Suchasnii stan. Perspektivi rozvitku (The 8th International Scientific and Practical Conference. Achievements, Restoration and Preventive Conservation of Museum Objects. Current State. Development Prospects). Kiev, 250-254 (in Ukranian).

Nikitin, M. K., Mel'nikova, E. P. 2002. Khimiia v restavratsii (Chemistry in Restoration). Saint Petersburg: "Khimiia" Publ. (in Russian).

Elkina, A. K. et. al. (comp.). 1987. Polevaia konservatsiia arkheologicheskikh nahodok (tekstil', metall, steklo) (Field Conservation of Archaeological Finds (Textile, Metal, Glass)). Moscow (in Russian).

1997. Obzor "O sostoianii okruzhaiushchei prirodnoi sredy Khanty-Mansiiskogo avtonomnogo okruga v 1996 godu" (Review "On the Environmental Condition of Khanty-Mansi Autonomous Okrug in 1996"), 20-25 (in Russian).

Polos'mak, N. V. 2014. In Nauka iz pervykh ruk (Science First Hand) 6, 64-87 (in Russian).

Polos'mak, N. V., Bogdanov, E. S. 2015. Kurgany Sudzukte (Noin-Ula, Mongoliya) (Burial Mounds of Sudzukte (Noin-Ula, Mongolia). Part 1. Novosibirsk: "INFOLIO” Publ. (in Russian).

Polos'mak, N. V., Bogdanov, E. S., Ceveendorge, D. 2011. Dvadtsatyi noin-ulinskii kurgan (The Twentieth Noin-Ula Mound). Novosibirsk: "Infolio" Publ. (in Russian).

Sinitsina, N. P. Opyt issledovaniia, restavratsii i rekonstruktsii predmetov arkheologicheskogo tekstilia iz nekropolia Voznesenskogo monastyria (The Experience of Study, Restoration and Reconstruction of Archaeological Textile Objects from the Necropolis of the Ascension Monastery). Available at: http:// art-fenomen.ru/restoration/publications/statya-2/ (accessed: 09.03.2021) (in Russian).

Plotnikov, V. V. 1997. Ekologiia Khanty-Mansiiskogo avtonomnogo okruga (The Ecology of KhantyMansi Autonomous Okrug). Tumen: "SoftDizain" Publ. (in Russian

\section{About the Authors:}

Shvets Olga L. Institute of Archaeology and Ethnography SB RAS. Acad. Lavretiev Avenue, 17, Novosibirsk, 630090, Russian Federation; ribcz@ngs.ru

Zaitseva Evgeniia A. Candidate of Historical Sciences, NIPI "Ethno-Archaeological Centre". Uralskaya str., 14, office 1002, 628013, Khanty-Mansiysk, KhMAO-Yugra, Russian Federation; e.zaitseva@archeocenter.ru

Kenig Aleksandr V. Candidate of Historical Sciences. Institute of Archaeology and Ethnography SB RAS. Acad. Lavretiev Avenue, 17, Novosibirsk, 630090, Russian Federation; akenig@bk.ru

Статья поступила в журнал 01.10.2021 г. Статья принята к публикации 01.12.2021 г. Авторы внесли равноценный вклад в работу. 